\title{
European Identity and European Heritage: A Critical Approach of Greek, British and Spanish Geography Textbooks
}

\author{
Apostolia Galani*, Athina Karatza \\ Department of Primary Education, National and Kapodistrian University of Athens, Athens, Greece \\ *Corresponding author: ligalani@primedu.uoa.gr
}

Received November 19, 2019; Revised October 21, 2019; Accepted December 25, 2019

\begin{abstract}
In this era of financial and migration crises that many European countries have been experiencing, together with a general feeling of dissatisfaction towards the European Union on the part of member states, questions about the formation of a shared European identity arise. This situation is aggravated by Europeans' low regard for or, in some cases, negative feelings about European identity, and by the lack of knowledge about European cultural heritage. Education plays a significant role in the shaping of identities - including a European one, while it also is responsible for preparing students, the citizens of tomorrow, for making decisions on a wide range of issues. Geography, which is a discipline that affects the construction of identity, is a useful perspective for studying the concepts of heritage and identities in the educational curriculum. This study was undertaken as a part of CoHERE, a project funded through Horizon 2020, which investigates - both comparatively and in depth - a carefully selected range of European territories and realities. Using qualitative descriptive analysis, a method for identifying, analysing and reporting patterns (themes) within data, we examined the relationship of education to the construction of a European identity by focusing on the extent to which European cultural heritage is recorded in textbooks in Greece, the United Kingdom, and Spain. Inferences are drawn on the way that these two concepts are presented in the textbooks, as well as the extent to which the key themes of Geography address these concepts. The findings of the study and their implications are discussed.
\end{abstract}

Keywords: European identity, European cultural heritage, geography textbooks

Cite This Article: Apostolia Galani, and Athina Karatza, "European Identity and European Heritage: A Critical Approach of Greek, British and Spanish Geography Textbooks.” American Journal of Educational Research, vol. 7, no. 12 (2019): 966-975. doi: 10.12691/education-7-12-11.

\section{Introduction}

The European crisis has already demonstrated its multifaceted consequences, affecting various aspects of the life of Europeans during the last few years. As a result, effects such as the sense of general discomfort, distrust towards and disaffection with the European Union (EU), Euroscepticism, negative feelings about possessing a European identity, as well as controversial trends (e.g. Brexit, rise of extreme right political groups, etc.), to mention but a few, have increasingly emerged, aggravating the already severe European crisis. This has led to questions about how a EU identity is/can be formed, and how the European cultural heritage can be shared, thereby creating a "bond" between people. To this end, our study was undertaken to examine the role of education in relation to these two concepts from the perspective of the discipline of Geography.

The two concepts - identities and cultural heritage - are closely linked. Identity is founded upon and enhanced through cultural heritage [1], while both concepts are closely connected with Space [2]. Identities emerge through socio-spatial interactions [3], while heritage creates a "sense of place" [4]. This interrelationship can be addressed by the educational discipline of Geography, which examines Space while it forms identities within a spatial context, including a European identity on the European continent. Moreover, cultural heritage consists of dimensions connected to Geography [5]. The key themes of geography - Location, Place, Human-environment interaction, Region, and Movement [6] - can be used for an overall geographical approach to European identity and heritage to enhance the understanding of the world's interactions and interconnections, forming geo-literate citizens with indispensable skills for modern societies [7].

The national, European, multicultural and global dimensions in education have been broadly studied [8]. Philippou, Karahasan and Latif [9] investigate the representations of "Europe" in Geography and Social Studies across the divide in Cyprus, defining categories of the various ways "Europe" is approached, i.e. as a geographic, economic, political, historical, and/ or cultural entity. Philippou [10] also examines the European dimension that could be used to decrease ethnocentrism in 
Greek Cypriot educational curricula. Resnik Planinc [11] examines the European dimension in Geography education in Slovenia, and suggests the inclusion of European identity issues within the framework of the European dimension in the teaching of Geography in that country. Faas [8] investigates the coexistence of cultural diversity and Europe in Geography, History and Citizenship curricula in three countries (Greece, Germany, and England) His study provides new insights into how national, European, multicultural and global dimensions intersect as well as their effect on migration and education in European societies. Brennetot's [12] analyses of textbooks from various countries to determine how Europe and the EU is represented revealed that the former is mostly presented as a continent with natural borders, while the latter is presented either as the outcome of a particular history through a linear perception which led to the creation of a "peaceful" Europe, or as a political project.

To date, the ways in which the European identity is constructed and the European heritage is transmitted to students via the representations in textbooks have not been examined through an analysis based on the key themes of Geography. This study aims to address that gap.

\section{Background}

The issues of identity and identity formation have long been discussed in the literature. Achkovska-Leshkovska and Davchev [13] argue that identity is defined as the set of characteristics, the image that someone has about himself/herself. An identity may be either personal/individual, referring to the characteristics related to only one person, or group/collective, referring to the feeling of identification with others. The formation of an identity encompasses the process of belonging, i.e. comparing and categorizing oneself as a member of an "in-group", and considering those who differ as "Others", i.e, members of an "outgroup” [14].

Identity is a constructed, learnable, and thus dynamic concept subject to change [15]. A person may simultaneously carry multidimensional (e.g. ethnic, religious, etc.) and multilevel identities (e.g. local, regional, national, continental, universal), which are context-dependent and may contain contradictions [14,16,17].

The "European identity" is a collective identity based on the co-existence of common elements inherent throughout the continent, which are present despite the multiple regional diversities (e.g. cultural, historical, linguistic, religious, etc.) inherited from the various ancient civilisations which form Europe's "roots" [18]. According to the literature, there are two components that comprise the formation of the European identity: the cultural and the political.

The first component, the formation of the European cultural identity, refers to "Europe as a cultural community of shared values" (i.e. human dignity, tolerance, freedom and equality, solidarity and democracy, and the "culture of remembering"), and originates from "common (cultural) legacies and (historical) experiences" [16]. A community has a cultural foundation, and its collective identity originates from a common language, history and culture. Cultural identity is strengthened by history, which is the cultural basis for the sense of belonging [16]. In addition, symbolic markers (e.g. a flag, mottos, an anthem, Europe Day, and a common currency) also create a sense of common belonging [11].

The second component, the formation of European political identity, refers to "Europe as a political community of shared democratic practices" through political structures such as the EU itself, the Council of Europe, and the EU institutions. European political identity is enhanced by constitutional patriotism ("active citizenship"), and by the EU's democratic structures and institutions. Both political and cultural components of European identity, if enhanced, contribute to the process of the formation of a shared European identity [16].

Identity formation processes are also connected to Space, among other factors. According to the structuralist model, identity construction follows bottom-up processes, since it is developed through socio-spatial interactions and relationships with others $[3,17]$.

The second major concept focused on in this study is cultural heritage, an element closely connected with identity. Cultural heritage is both the cornerstone of identity and a means to further develop and enhance it [1]. Heritage is a broad and increasingly expanding term, referring to a growing number and range of things [19] and describes anything solid/tangible or ethereal/intangible, originating from either the natural or the human environment.

The term cultural heritage encompasses several main categories, according to UNESCO [20] (www.unesco.org) and Harrison [19]:

- Tangible and intangible cultural heritage. Tangible encompasses the movable cultural heritage (i.e. paintings, sculptures, coins, manuscripts, etc.), the immovable cultural heritage (i.e. monuments, museums, ruins, buildings, etc.), the underwater cultural heritage (i.e. shipwrecks). Intangible cultural heritage consists of oral traditions, stories, myths, languages, literature, culinary traditions, etc.

- Natural heritage, which refers to natural sites with cultural aspects, such as cultural landscapes, and physical, biological, or geological formations.

- Heritage in the event of armed conflict refers to the protection of any elements of cultural heritage types listed above from destruction by warring factions. This aspect of cultural heritage is not included in our study.

Heritage connects people, objects, places and practices [19], while different cultures and heritage(s) are also interconnected. Items that constitute heritage need to be safeguarded and preserved, since a devastation of a cultural element not only implies the destruction of identity [21], but also entails degradation for all heritages [19]. Heritages, apart from being Space related, are also Time related. Because of the role of heritage in "embedding" the past into the present, the values associated with and represented through it accompany people, and influence them in the creation of their future. This was confirmed by the findings of several studies $[5,19]$, in which representations of cultural artifacts in video games were analysed, and their findings showed that several dimensions of cultural heritage were included 
in the games (Table 1). Specifically, they found key tangible and intangible components of cultural heritage connected to Geography (e.g. the environment, landscape and climate).

Table 1. Dimensions of Cultural Heritage

\begin{tabular}{|c|c|c|}
\hline Themes & Tangible Dimensions & $\begin{array}{c}\text { Intangible } \\
\text { Dimensions }\end{array}$ \\
\hline $\begin{array}{c}\text { Arts and } \\
\text { Artifacts }\end{array}$ & $\begin{array}{c}\text { Architecture; Sculpture; Visual } \\
\text { Image; Documents and Writing; } \\
\text { Performance arts; Clothing; }\end{array}$ & $\begin{array}{c}\text { Language; Music; } \\
\text { Folklore }\end{array}$ \\
\hline Environment & $\begin{array}{r}\text { Places of Scenic Interest; } \\
\text { Landscape }\end{array}$ & Climate \\
\hline People & People & Behaviour \\
\hline History & $\begin{array}{c}\text { Historic Sites; Historic Artifacts; } \\
\text { Historic People }\end{array}$ & $\begin{array}{c}\text { Customs; Time; } \\
\text { Ages }\end{array}$ \\
\hline
\end{tabular}

The present research forms part of a broader study that aims to examine and analyse the construction of European identities (both cultural and political) and the introduction to aspects of cultural heritage (tangible/intangible, natural) through the curricula of Geography education, as presented in school textbooks from three EU member states. We believe that cultural heritage is connected to Geography (i.e. natural heritage, heritage and environmental factors, etc.), and thus can be studied through geographical approaches.

\section{Methodology}

This paper examines the extent to which concepts of European identities and cultural heritage are developed through the curricula of formal education in three European member states; specifically, a count was made of the number of relevant references in textbooks used in Greece [22-29], the United Kingdom (UK) [30-38], and Spain [39-48], as well as when and how these concepts are presented to students.

A study of the construction of European identity and cultural heritage has already been presented in the e-book "Geographical literacy and European heritage: A challenging convention in the field of education” $[2,49]$. A geographical perspective was followed in that study, since identities [3] and heritage are both Space-dependent [4].

Based on the findings of the studies referenced above, we believe it is particularly important to examine the role of textbooks in European identity formation and acquainting students with European cultural heritage in order to draw inferences on the way that these concepts are presented and taught. In this paper, which is only one part of a larger project, the study and analysis of the texts concerning European identity and cultural heritage within the textbooks of three countries will be presented.

\subsection{Research Questions}

The questions formulated to serve the aims of the research were the following:

- To what extent does the concept of European identity (both cultural and political identity) appear in the textbooks of the three sample countries? How is it represented?
- To what extent does the concept of European cultural heritage exist in the textbooks of the three sample countries? How is it recorded?

\subsubsection{Selection Criteria for the Sample Countries}

The first step was the selection of the countries whose textbooks would be used in the study. Greece, Spain and the UK were selected due to common socioeconomic characteristics they currently share: They have all undergone a series of crucial changes due to globalisation, migration, and multiculturalism, among other factors.

Greece, Spain and the UK are destination countries for immigrants. In Greece, for example, more than 160,000 immigrants arrived in 2016. On the other hand, due to financial and social uncertainty and insecurity, the "braindrain" phenomenon has become more intense in Greece and Spain as young, highly-skilled individuals emigrate in order to achieve a better standard of living and quality of life, higher salaries, access to advanced technology, and more stable political conditions [50,51]. According to those authors, the large majority of "brain losses" from Greece and Spain were recorded as "brain inflows" for the UK. However, these inflows triggered political debate (part of the Brexit referendum discussion) about migration within the UK.

Another common characteristic shared by Greece and Spain is that they have been greatly affected by the European financial crisis and austerity measures, having much higher unemployment rates $(20.6 \%$ in Greece and $16.7 \%$ in Spain in 2017) compared to the UK (4.3\%) during the same period [52]. The economic crisis and the failure of the EU to address the economic problems that had been developing since 2008, together with the rise of nationalism around the world, have raised many issues regarding the (dis)advantages of membership in the EU, including leaving it. The UK, for example, held a referendum on this issue and, based on the outcome, notified the European Council of its "Brexit" decision [53] The multidimensional crises (financial, migration etc.) in Spain and Greece, along with Brexit in the UK, have increased Euroscepticism [54], while questions concerning a member state's relationship with Europe and the European identity have arisen.

\subsubsection{Selection Criteria for the Sample Textbooks}

The next step was the selection of the textbooks that corresponded to the relevant curricula for purposes of our analysis. The criteria used to select the sample of textbooks were the students' ages and level of compulsory schooling, following the criteria previously used in the selection of curricula of specific grades and disciplines which is presented in detail in a previously published paper [49].

In the case of Greece, the same textbooks for each subject in every grade are used in all Greek schools, were created and first approved in 2008-2009 by the former Pedagogical Institute (now called The Institute of Educational Policy), and subsequently approved by the Hellenic Ministry of National Education, Research and Religious Affairs. Since 2013, the books are published by the company CTI Diophantus. The textbooks analysed in this paper are those currently used in Greek schools (year of publication 2017-2018) [22-29]. 
In the UK and Spain, however, a variety of textbooks by different authors and publishers are used. Therefore, in order to decide which textbooks to analyse in this study, the popularity of the textbooks among the teachers who use them was the criterion applied. Since no statistical data regarding textbooks sales was available, we contacted teachers' professional associations in both countries.

In the case of the UK, the Geographical Association responded that "a lot of schools use the Oxford University Press publication Geography 1, 2 and 3 at the Key Stage 3 level.” However, since there was no official response from any British teachers' professional association about textbooks used in Key Stages 1 and 2, we examined and analysed the textbooks that were designed for international use and had been recently written [30-38].

Regarding the selection of the Spanish textbooks, the Spanish Federation of History and Geography Teachers (Federación Española del Profesorado de Historia y Geografía) responded that textbooks "should only be incorporated into the classroom library for consultation, and [that teachers should] use more active pedagogies, more varied, sometimes with technological means, and information [on the internet], which leaves the use of the textbook far behind". Due to the fact that no specific publications were recommended, pedagogical criteria, such as the cohesion of the didactic material and the richness of content, were applied. There are many well known publishers in Spain, S.M., Anaya, and Santillana being some of the most popular ones. Some publishers, such as S.M., provided a sample chapter (preview) online. Anaya provided us with access to their material for viewing but, unfortunately due to budget limitations, access to all the textbooks was not possible. In addition, in Spain each publisher differentiates the contents of its textbooks according to the autonomous community where they are intended to be sold. For our research, textbooks used in Madrid, the capital of Spain, were chosen and analysed [39-48].

Table 2 presents the textbooks of the three countries that were eventually selected for analysis.

Table 2. Textbooks examined in the analysis

\begin{tabular}{|c|c|c|}
\hline Countries & Textbooks examined & Publishers \\
\hline Greece & $\begin{array}{c}\text { Environmental Studies } \\
{[22-25]} \\
\text { Geography }[26,27] \\
\text { Geology-Geography } \\
{[28,29]}\end{array}$ & $\begin{array}{l}\text { CTI, Diophantus (2017- } \\
\text { 2018) }\end{array}$ \\
\hline UK & Geography [30-38] & $\begin{array}{l}\text { Oxford University Press } \\
(2014,2015)\end{array}$ \\
\hline Spain & $\begin{array}{c}\text { Social Sciences [39-44] } \\
\text { Geography and History } \\
{[45-48]}\end{array}$ & $\begin{array}{c}\text { Anaya Series: Aprender es } \\
\text { crecer }(2014,2015) \\
\text { S.M. Savia }(2015,2016)\end{array}$ \\
\hline
\end{tabular}

In order to answer the research questions, content analysis of the textbooks was conducted. According to [55], the aim of content analysis is the extraction of valid inferences from texts. After the units of analysis and the categories had been defined, the textbooks were examined and, finally, the results were interpreted.

The data was analysed using two approaches: qualitative and quantitative. In the qualitative analysis, the concepts of European identity and cultural heritage where viewed from a geographical perspective in order to draw inferences on the manner through which students both construct and develop their identities, and come into contact with European cultural heritage. The quantitative analysis consisted of counting the textbook references that were related to European identity and cultural heritage in order to define the extent to which they appear in the textbooks used in the three sample countries. The codes shown in Table 3 were used to identify the elements that compose each of the two concepts studied.

Table 3. Codes used to identify elements of the studied concepts

\begin{tabular}{|l|l|}
\hline Concepts & Codes \\
\hline \multirow{2}{\text{European}}{$\begin{array}{l}\text { Political identity, e.g. political democratic structures, such } \\
\text { as EU institutions and other bodies, European borders, etc. } \\
\text { Cultural identity, e.g. common cultural legacies-historical } \\
\text { experiences, EU symbolic markers (e.g. the flag, motto, } \\
\text { anthem, Europe Day, common currency, etc.), shared values } \\
\text { (e.g. human dignity, tolerance, freedom and equality, } \\
\text { solidarity, and democracy). }\end{array}$} \\
\hline $\begin{array}{l}\text { European } \\
\text { cultural } \\
\text { heritage }\end{array}$ & $\begin{array}{l}\text { Tangible/intangible heritage, attitudes towards European } \\
\text { heritage (e.g. preservation of historical sites, protection of } \\
\text { the environment, flora and fauna, etc). }\end{array}$ \\
\hline
\end{tabular}

References to the concepts of European identity and cultural heritage within the textbooks were recorded. In our analysis, references to both the EU and the European continent were included, since the term "Europe" is used ambiguously as an "umbrella" concept for both entities.

The relevant references were also categorised according to the key themes of Geography. References within the textbooks that were in the context of other disciplines (e.g. History, Civics) rather than the key themes of Geography were counted and classified according to the respective subjects.

The optional abstracts or supplementary information at the end of the units were included in the research, since they amplify the unit content. Textbook activities were only analysed when they enriched the content of the text. The schemes or mental maps designed to facilitate students' reflection on and/or understanding of the unit material were not counted, since they did not present new material, but rather were a revision of concepts already taught.

\section{Analysis of the Data}

There were differences in both the number of references to the concepts focused on in this study, and differences in the grade levels the concepts were introduced to students (Table 4).

Table 4. Dimensions of Cultural Heritage

\begin{tabular}{|c|c|c|c|}
\hline \multirow{2}{*}{ Concepts } & \multicolumn{3}{|c|}{ Number of references in textbooks } \\
\cline { 2 - 4 } & Greek & British & Spanish \\
\hline European Identity & 164 & 3 & 99 \\
\hline European Heritage & 139 & 28 & 22 \\
\hline Total References & 303 & 31 & 121 \\
\hline
\end{tabular}

As can be seen from Table 4, Elements of European identity and cultural heritage are taught to Spanish students through almost all grades of compulsory education (i.e, second-sixth grades of primary school, and 
all grades of secondary school), while Greek students learn about these concepts mainly through three grades (i.e., fifth and sixth grades of primary school and the second grade of secondary school. Only a few references were found in the Greek textbooks for the fourth grade of primary school). As for the British textbooks, the references recorded are mainly found in Key Stages 1 and 2 .

\subsection{European Identity}

Table 5 presents the references found in the sample textbooks that relate to the two crucial components of European identity: the political and the cultural.

Table 5. References to European identity (political and cultural) in the textbooks

\begin{tabular}{|l|c|c|c|}
\hline \multirow{2}{*}{ European Identity } & \multicolumn{3}{|c|}{ Number of references in textbooks } \\
\cline { 2 - 4 } & Greek & British & Spanish \\
\hline Political & 129 & 3 & 89 \\
\hline Cultural & 35 & - & 10 \\
\hline Total References & 164 & 3 & 99 \\
\hline
\end{tabular}

\subsubsection{European political identity}

As shown in Table 5, 129 references to the political component of European identity were found in Greek textbooks, and 89 in the Spanish books. The references contained information about the following aspects of the EU: its definition, its member states and its developmental phases, its borders, the Eurozone, its institutions, its laws, and the advantages of being part of it, along with the problems and the challenges that the EU. As regards the British textbooks, only three relevant references are found, and those concern the countries of Europe and the European borders. References to the EU are absent. A summary of the references for each of the above subcategories is shown in Table 6.

Table 6. References to the subcategories of European political identity in the textbooks

\begin{tabular}{|l|c|c|c|}
\hline \multirow{2}{*}{$\begin{array}{l}\text { European political identity: } \\
\text { subcategories }\end{array}$} & \multicolumn{3}{|c|}{ Number of references in textbooks } \\
\cline { 2 - 4 } & Greek & British & Spanish \\
\hline EU Borders & 8 & 3 & 6 \\
\hline Definition of the EU & 5 & - & 4 \\
\hline EU member states & 22 & - & 8 \\
\hline EU accession Phases & 16 & - & 19 \\
\hline EU institutions & 16 & - & 14 \\
\hline The Eurozone & 8 & - & 6 \\
\hline Aims of the EU & 12 & - & 7 \\
\hline EU economic characteristics & 5 & - & 3 \\
\hline $\begin{array}{l}\text { EU Laws (presented as providing } \\
\text { advantages to member states) }\end{array}$ & 35 & - & 11 \\
\hline $\begin{array}{l}\text { Problems and challenges of the } \\
\text { EU }\end{array}$ & 2 & - & 11 \\
\hline Total References & 129 & 3 & 89 \\
\hline
\end{tabular}

It is worth noting that the problems and the challenges faced by the EU are only examined in the second grade of Greek secondary school and the fourth grade of the Spanish secondary school (except for one reference found in the third grade of the same level). In the Greek textbooks, there were no references to either the economic crisis or the problems which confront the EU.

The problems and the challenges faced by the EU were divided into subcategories, and the number of references was recorded (Table 7).

Table 7. References to the subcategories of European political identity in the textbooks

\begin{tabular}{|l|c|c|}
\hline \multirow{2}{*}{$\begin{array}{l}\text { European political identity: Problems and } \\
\text { challenges of the EU }\end{array}$} & \multicolumn{2}{|c|}{$\begin{array}{c}\text { Number of references } \\
\text { in textbooks }\end{array}$} \\
\cline { 2 - 3 } & Greek & Spanish \\
\hline The economic crisis and/or its negative effects & - & 3 \\
\hline Exiting the EU (motives) & - & 2 \\
\hline Fractioning of the EU & - & 1 \\
\hline Insufficient institutional structure & - & 1 \\
\hline Slow reaction to crises / lack of agreement & - & 2 \\
\hline $\begin{array}{l}\text { Internal economic, political, cultural differences } \\
\text { (the EU North vs the EU South) }\end{array}$ & - & 1 \\
\hline Anti-European political parties & - & 1 \\
\hline Unemployment and homelessness & 1 & - \\
\hline Environmental problems & 1 & - \\
\hline Total References & 2 & 11 \\
\hline
\end{tabular}

In this part of the study, only Greek and Spanish textbooks were analysed since, as previously mentioned, no relevant references were found in the British textbooks. We also found that the majority of the references in the Greek and Spanish textbooks (i.e. 69 of 129 and 61 of 89, respectively) which were intended to consolidate the concept of European political identity in students' minds were, in general, not based upon key themes of Geography, but rather upon elements originally taught in Civics classes. In contrast, the three references regarding European political identity found in the British textbooks used the geographical theme of Location.

\subsubsection{European Cultural Identity}

As shown in Table 8, Greek and Spanish textbooks referred to elements that involve the cultural component of the European identity (35 and 10 references, respectively), such as the symbols of the EU, its values (human dignity, tolerance, freedom and equality, solidarity and democracy), and the many languages and religions that exist in Europe. The British textbooks did not include any references relating to the European cultural identity. In Greek and Spanish textbooks, the majority of the references (27 of 35, and 9 of 10 references, respectively) are not based upon themes of Geography, but rather upon elements originally studied in History.

Table 8. Subcategories and references to European cultural identity in the textbooks

\begin{tabular}{|l|c|c|}
\hline \multirow{2}{*}{$\begin{array}{l}\text { European cultural identity: } \\
\text { subcategories }\end{array}$} & Number of references in textbooks \\
\cline { 2 - 3 } & Greek & Spanish \\
\hline EU symbols & 7 & 8 \\
\hline EU values & 20 & 1 \\
\hline EU languages and religions & 7 & 1 \\
\hline EU Social-cultural goals & 1 & - \\
\hline Total & 35 & 10 \\
\hline
\end{tabular}


Greek students mainly study EU values (15 of 20 relevant references) during the second grade of secondary school, while Spanish textbooks do not focus on this theme: Only one reference (without any explanation) was found in the Spanish textbooks, and that book was used in the sixth grade of primary school). No relevant references were found in the British textbooks analysed.

\subsection{European Cultural Heritage}

As regards the concept of European cultural heritage, many relative references are recorded in Greek textbooks, the majority of which refer to the history of Europe and the EU. There are also many references to intangible heritage, to common cultural elements shared by Europeans, and on the interrelationship between a place and its characteristics to European life.

In contrast, Spanish textbooks contain few references to the European cultural heritage. Students are not taught about elements such as common European cultural characteristics, the influence of the environment on European life and activities, or the influence of the participation in international networks on a culture. Finally, in British textbooks, the majority of the references deal with the spatial characteristics that influence European life and activities, such as the influence of the climate on tourism and leisure activities, the food heritage connected to a specific location and place, and the role of the rivers on the growth of cities. These results are summarized in Table 9.

It is worth noting that in both Greek and Spanish textbooks, the majority of the references (63 of 139, and 10 of 22, respectively) are based on elements originally studied in History rather than on themes of Geography. On the other hand, British textbooks used themes of Geography almost exclusively to construct the 23 of 28 references found. (The remaining five British references were based upon History and Civics.)

Table 9. Subcategories and references to European cultural heritage in the textbooks

\begin{tabular}{|l|c|c|c|}
\hline \multirow{2}{*}{$\begin{array}{l}\text { European cultural heritage: } \\
\text { subcategories }\end{array}$} & \multicolumn{3}{|c|}{ Number of references in textbooks } \\
\cline { 2 - 4 } & Greek & British & Spanish \\
\hline Tangible & 11 & 5 & 2 \\
\hline Intangible & 24 & 4 & 3 \\
\hline Common cultural elements & 18 & - & - \\
\hline Cultural diversity & 9 & - & 1 \\
\hline Place related to life and activities & 28 & 15 & - \\
\hline Heritage in general & 13 & - & 1 \\
\hline History of Europe / the EU & 36 & 4 & 15 \\
\hline Total References & 139 & 28 & 22 \\
\hline
\end{tabular}

\subsection{The Role of the European "place"}

The key themes of Geography most frequently used in the textbooks to consolidate the two concepts examined are Location and Place (see Table 10). As regards the theme of Place, in both Greek and Spanish textbooks, only a small number of references to the European Place (53 and 27, respectively) is linked to the concepts of European heritage and identity, in comparison to the British textbooks, on the other hand, in which most of the references concerning the European Place, although few in number, lead to the study of elements of European cultural heritage.

Table 10. The Geographical theme of Place in relation to European identity and cultural heritage in the textbooks

\begin{tabular}{|c|c|c|c|c|}
\hline \multirow{2}{*}{ European Place } & \multicolumn{3}{c|}{ Number of references in textbooks } \\
\cline { 3 - 5 } & Greek & British & Spanish \\
\hline \multirow{2}{*}{ connected to: } & EU identity & 24 & - & 20 \\
\cline { 2 - 5 } & EU heritage & 29 & 20 & 7 \\
\hline \multirow{2}{*}{$\begin{array}{c}\text { not connected } \\
\text { to: }\end{array}$} & $\begin{array}{c}\text { Total } \\
\text { EU }\end{array}$ & 53 & 20 & 27 \\
\hline \multicolumn{2}{|c|}{ Total References } & 203 & 51 & 43 \\
\hline
\end{tabular}

\section{Discussion}

In the Greek and Spanish textbooks examined, the concepts which are the focus of this study - European identity and cultural heritage - are often included, but are not introduced gradually and developed during all grades of primary and secondary school so that students adopt them, while in the British textbooks, the concepts are only occasionally mentioned. One explanation for the occurrence of more references in Greek textbooks (303) compared to Spanish textbooks (121) is that in Greece, the second grade of secondary school focuses exclusively on the study of Europe.

\subsection{European Political Identity}

European political identity is developed in students through many references in Greek and Spanish textbooks (i.e. the definition of the EU, its member states, the phases of its formation, its institutions, some of its laws, etc.). In contrast, few references were recorded in the British books.

In Greek textbooks, the EU is presented as an evolving entity, constantly adapting to accommodate the addition of new member states, providing economic and social benefits (e.g. free movement of goods and people, etc.) to its members, but at the same time still having many tasks to accomplish. This structured and descriptive depiction does not help students comprehend that the EU is a dynamic system which must accommodate the diverse opinions and ideologies of its member states, a situation which often results in the failure to reach unanimous agreement on issues or policies, or that there are actual problems, and controversies occurring now that need to be dealt with (e.g. the economic and migration crises, environmental pollution, unemployment, etc.).

References in the curricula to the problems and the challenges that the EU faces are essential, particularly in countries that have been greatly affected by present conditions (e.g. the economic crisis in Greece, and Brexit in the UK). However, there were only two references in Greek textbooks, and those are related to unemployment and environmental issues, and no references to any of the key issues occurred in British textbooks.

Considering that actual problems and how to overcome them are not discussed in compulsory education in Greece and the UK, future citizens of those countries will be 
called upon to make decisions that will affect both their country and the EU without having previously acquired the necessary background to critically reflect upon them.

On the other hand, in Spanish textbooks, actual problems within the EU (e.g. social/economic imbalances between member states) and ways to promote cohesion by finding solutions to them (e.g. EU-funded infrastructure projects) are discussed in secondary school. Major problems which Spanish students are informed about include the economic crisis and its negative effects (e.g. economic inequalities), emergency loans to some member states, the intention of some members to leave the EU, the lack of agreement between member states on critical issues, and their slow and inefficient reaction to them (e.g. the 2015 refugee crisis).

It should be mentioned that the Greek textbooks have not been updated since they were written (2007-2009), which was prior to the time when the full extent of the Greek economic crisis had become apparent. Other information in the Greek textbooks is markedly outdated and incorrect, such as there being 27 EU member states instead of 28, and that only 13 countries are members of the Eurozone, instead of the actual 19.

The fact that most references intended to consolidate the concept of European political identity were generally based upon elements originally taught in Civics rather than on key themes of Geography was expected, since the focus of this part of the present study was on European political identity. However, political issues both derive from and affect societies, and their characteristics (e.g. human belief systems, settlement patterns, economic activities, etc.) can advantageously be examined through several key themes in Geography, such as Place, Movement, and Region.

\subsection{European Cultural Identity}

Our findings indicate that after completion of their compulsory education, Greek students will have come into contact with many elements of the European cultural identity (35 references), mostly during the second grade of secondary school. Spanish students will have learned about relatively few elements relating to this concept (only 10 references were recorded), while UK students will not have studied any elements involving European cultural identity. Symbols which have the ability to create a common sense of belonging are rarely mentioned in Greek and Spanish textbooks (7 and 8 references, respectively). Symbols are approached superficially, as typical and abstract elements. They are not linked to the current political stage, and their significance is not emphasized to students.

In the cases of Greece and Spain, the common European values that enhance unity among Europeans are not, in general, emphasized or apparent to the citizens of those countries, and it is therefore not surprising that no goals have been set for their comprehensive inclusion in the primary and secondary school curricula. As a result, the concepts are taught in a relatively casual or indirect way, an approach which is not likely to produce in students a strong psychological bond to the EU and its people.
In both Greek and Spanish textbooks, the majority of references to European cultural identity were not based on themes of Geography, but upon elements originally studied in Civics.

\subsection{European Cultural Heritage}

As is true for European cultural identity, in both the Greek and Spanish textbooks, the majority of references to European cultural heritage were not based upon themes of Geography, but rather upon elements originally studied in History. This result was expected since the category History of Europe contained the most references in both countries. On the other hand, British textbooks used themes of Geography to refer to European cultural heritage almost exclusively.

There are two basic reasons why the majority of the references in the Spanish textbooks occur in the subcategory of History. Firstly, in primary education, the Social Studies part of the curriculum includes four content blocks, one of which, entitled "Traces of Time", focuses entirely on the important historical periods of humanity. Secondly, during the fourth grade of Spanish secondary school, the disciplines of Geography and History are approached without a distinction being made between them.

Negative aspects of the cultural history of Europe (i.e. dictatorships, wars, imperialism, intolerance, Euroscepticism, opposition to the perceived technocracy of the EU, etc.) that could be examined through the key themes of Geography are mentioned in the textbooks, but very few were recorded in Greek textbooks (i.e. six references concerning wars at the sixth grade of primary school and the second grade of secondary school) and Spanish textbooks (i.e. three references in the fourth grade of secondary school concerning the petroleum crisis, dictatorships, wars, the economic crisis and the danger of the collapse of the EU, as well as the pressure and social unrest due to long-term austerity measures). This "selective" (in the case of the Greek textbooks) and "occasional" (in the case of the Spanish textbooks) vision of European history implies a linear historical process in which peoples of both countries accept mutual values and set common goals in a general climate of tacit acquiescence. This approach, being mostly Eurocentric and comforting compared to reality - especially in the case of the Greek textbooks - does not encourage pupils to learn from the historiographical debates which highlight both the fragility and importance of maintaining peace that marked human history [12]. This idealistic perspective does not empower students to think critically not only about what happened in the past, but also how to remember it.

\subsection{The role of the European Place}

Geography is a discipline that examines not only the physical characteristics of places, but also of humans. In order to acquire Geoliteracy [56], students' knowledge about Places should be extended to include possible interactions between the natural world and the humans who inhabit it (e.g. social, cultural, economical, and 
historical interactions), both within a particular Place, as well as interconnections to other Places. While emphasis is focused on the key theme of Place in the curricula about Europe, the way information is presented does not lead to the development of European identity or acquaintance with European heritage and cultures. For example, while climate, local flora, forest cover, hydrography, seismicity, volcanoes and other physical characteristics of the European Place are taught, the ways that these elements affect the lives, the activities and the customs of the Europeans are not mentioned.

Another missed opportunity is the way physical networks, such as international rivers, lakes and tunnels, are presented. Although their physical attributes may be described, their role in the development of cultures, societies and economies, the connection of places and peoples, the facilitation of the interaction and exchange of elements of cultural heritage, and the movement of people, ideas and products, are not discussed. A final example is that of the agricultural and industrial sectors of Europe; these are studied, but the ways they affect customs, food heritage, traditional products, and other factors are not examined.

However, it should be noted that textbooks follow the structure of the curricula, and therefore it is normal that their content does not deviate much from that. Moreover, the educational context of each country (i.e, the curricula definition and design, subjects to be taught, amount of freedom given to teachers, etc.) influences the way the textbooks are used [12], which differs among the three countries studied. In Spain and the UK, the textbooks are mainly used for consultation, while in Greece teachers are required to teach the material in the national textbooks.

\section{Conclusions}

Multifaceted crises in Europe (economic, refugee, etc.), along with the Brexit decision, have raised questions among member states about the stability and effectiveness of the EU, an atmosphere which gave rise to Euroscepticism. The crucial concepts of a European identity and European cultural heritage which would serve as a means to bond citizens of member states together seems to be lacking.

To gauge the degree to which educational systems contribute to the development of these concepts, a number of studies were conducted. In our research, Greek, British and Spanish textbooks were studied and analysed since identities are founded upon cultural heritage, which is connected to Geography. Thus, we approached this issue from a geographical perspective, using the five key terms of geography: Location, Place, Human-Environment Interaction, Movement and Region.

According to our findings, European identity formation and acquaintance with its cultural heritage is generally not being developed in educational curricula through the key themes of Geography in the countries studied. More references to European identity and cultural heritage were found in Greek textbooks than in the British. In the Greek textbooks, the majority of references occurred in the second grade of secondary school, where Europe is studied almost exclusively. However, since the Greek curricula (and therefore the textbooks) are outdated, students are not acquainted with the current challenges facing the EU and how to confront them.

As regards the European values presented in Greek, Spanish and British textbooks, it was found that they are not gradually introduced, expanded upon, and consistently reinforced throughout the years of compulsory education so that students assimilate them. This limitation, coupled with the very few references to EU symbolic markers, leads to poor development of the cultural dimension of the European identity.

The "themes of Geography" that offer a multidimensional, spatial approach, do not play a major role in the curricula of the countries studied, and are not adequately used to introduce and enhance the aforementioned concepts. Most references include elements originally taught in other disciplines (e.g. Civics and History). When the key themes of Geography are used, emphasis is mainly put on the European Place, which - although important - is only an isolated element when not connected to cultural heritage, and therefore by itself does not facilitate the development of European identity in students. Instead, students are left with a poor understanding of the systemic interactions of how the world works (e.g. European economic, political, cultural and social systems), and of the historical, geographical and social interconnections between places (e.g. a particular country and Europe), further compromising their development as critical thinkers, decision makers and geoliterate citizens, as regards issues of the European continent and the EU. Geoliteracy is a vital characteristic of modern society [7] since it enables citizens to make systematic, well-reasoned decisions. It requires one to comprehend the world's systematic interactions, and the interconnections between places, regions and continents [57]. To that end, the key themes of Geography in school textbooks is of great importance in creating an overall foundation for the concepts of EU identity and cultural heritage.

Based on the analysis conducted, it is likely that after completion of compulsory education, students will have been exposed to few - or inadequately informed about aspects of European identity and cultural heritage.

Therefore, there is a necessity to offset this shortcoming by creating materials for students which will introduce, develop, and reinforce the concepts of European cultural heritage and identity. For this purpose, educational material entitled "Communicating Critical Heritage and Geography with pupils (Activity Book - Brochures for educators)" has been created [58,59]. It encompasses structured lesson plans and worksheets focused on "European Identity and Heritage", the "European Other" and the "Sense of Place", and its goal is to empower students to create brochures in order to communicate their findings and their ideas concerning Critical Heritage and Geography.

Nonetheless, the mere exposure to elements connected to European cultural heritage is not sufficient for an identity to be constructed. Identity formation is not developed in a spatial and social vacuum since it emerges through socio-spatial interactions [3]. Students, who build their understandings through their personal experiences, should have opportunities to come into contact with European places and people, either through a direct or 
indirect interaction. The latter could be achieved by making use of Information Technology (IT).

For this purpose, an online educational game called "Eurocraft: Explore Critical Heritages through Vid-Maps" has been developed. Its aim is to promote the communication of cultural heritage(s) between people in Europe and the difficult past and present they share, as well as to encourage dialogue about and understanding of the "European Other" [60,61]. Specifically, the goal is for students to investigate the material they upload, the informational content of the games they play, and the dot maps of heritage distributions they create (vid-maps) by combining thematic layers of heritage information.

Further research regarding the content of textbooks and school atlases in the three countries evaluated in this study will be conducted in future. The study will include (a) the way in which national identities, the "European Other", and the "sense of Place" are presented in the textbooks, (b) relevant maps, images, charts and graphs in the textbooks, (c) the way these concepts are structured, and (d) the dialogue developed between students concerning heritage. The aim is to identify those elements that would lead to the ideal dialogue for promoting European identity. In addition, a detailed comparison between the textbooks and the curricula will be made.

\section{Acknowledgements}

The research is part of the CoHERE project that has received funding from the European Union's Horizon 2020 research and innovation programme under grant agreement 693289.

\section{References}

[1] Tsaliki, L., The construction of European identity and citizenship through cultural policy. European studies: a journal of European culture, history and politics. 24: 157-182, 2007.

[2] Galani, L., Geographic literacy, European identity and Education In Galani, L., E. Mavrikaki and K. Skordoulis (eds.) e-book Geographical literacy and European Heritage: a challenging convention in the field of Education, Solva Tech LTD, Limassol, ISBN: 987-992597439-2-6, 2018, [E-book] Available: https://itunes.apple.com/us/book/geographical-literacy-andeuropean-heritage/id1444840569?ls=1\&mt=11.

[3] Recchi, E., Pathways to European identity formation: a tale of two models. Innovation: The European Journal of Social Science Research. 27(2): 119-133, 2014.

[4] Davis, P., Ecomuseums: A Sense of Place. 2nd ed. London: Continuum International Publishing Group, 2011.

[5] Balela, M. S. and Mundy, D., Analysing Cultural Heritage and its Representation in Video Games, Proceedings of Digital Games Research Association DiGRA 2011 Conference: Think Design Play, 2011.

[6] Joint Committee on Geographic Education, Guidelines for Geographic Education: Elementary and Secondary Schools. Washington, D.C.: National Council for Geographic Education and Association of American Geographers, 1984.

[7] Galani, L., Geo-Literacy as the basis of the Building of Cultural Identity. European Journal of Geography. 7(1): 17-23, 2016.

[8] Faas, D., The nation, Europe and migration: A comparison of geography, history and citizenship education curricula in Greece, Germany and England. Journal of Curriculum Studies. 43: 471-92, 2011.

[9] Philippou, S., Karahasan, H. and Latif, D., What room for European Citizenship? Exploring constructions of "Europe" in geography curricula across the divide in Cyprus. In Ross, A. and
Cunningham, P. (eds.) Reflecting on Identities: Research, Practice and Innovation. London: CiCe. pp. 431-444, 2008.

[10] Philippou, S., Re-inventing Europe: the case of the European dimension in Greek-Cypriot geography and history curricula. The Curriculum Journal. 18(1): 57-88, 2007.

[11] Resnik Planinc, T., European dimension and European identity through the perspective of geography teaching in Slovenia Rasprave. 37: 5-25, 2012.

[12] Brennetot, A, Europe representations in textbooks. halshs00648767, 2011, https://halshs.archives-ouvertes.fr/halshs00648767 (Accessed 2018-12-09).

[13] Achkovska-Leshkovska, E. and Davchev, V., Intercultural education: Analysis of the primary school textbooks in the Republic of Macedonia. International Journal of Cognitive Research in Science. Engineering and Education. 1(2), 2013.

[14] Papaeconomou, A., National versus European identity: The dimensions of change, defining Greek teachers' European identity. Preschool \& Primary Education. 2(1): 45-58, 2014.

[15] Smith, A. D., Nations and nationalism in a global era. Cambridge: Polity, 1995.

[16] Prutsch, M. J., Research for CULT Committee - European Identity. European Parliament, Policy Department for Structural and Cohesion Policies. Brussels, 2017, http://www.europarl.europa.eu/RegData/etudes/STUD/2017/5859 21/IPOL_STU(2017)585921_EN.pdf (Accessed 2019-5-17).

[17] European Commission, The Development of European Identity/Identities: Unfinished Business. A Policy Review. European Commission. Directorate-General for Research \& Innovation. Brussels, 2012, https://ec.europa.eu/research/socialsciences/pdf/policy_reviews/development-of-european-identityidentities_en.pdf (Accessed 2017-12-17).

[18] Pinxten, R., Cornelis, M. and Rubinstein, R. A., European Identity: Diversity in Union. International Journal of Public Administration. 30: 687-98, 2007.

[19] Harrison, R., Heritage, Critical Approaches. New York: Routledge, (2013).

[20] UNESCO, What is meant by "cultural heritage"?, (no date), http://www.unesco.org/new/en/culture/themes/illicit-traffickingof-cultural-property/unesco-database-of-national-cultural-heritagelaws/frequently-asked-questions/definition-of-the-culturalheritage/ (Accessed 2019-09-23).

[21] Albert, M.T. and Ringbeck, B., 40 years world heritage convention. Popularizing the protection of cultural and natural heritage. Berlin: De Gruyter, 2015.

[22] Plakitsi, K., Kontogianni, A. Spiratou, E. and Manoli, V., Study of the Environment, $1^{\text {st }}$ grade of primary school. Athens, CTI Diophantus (in Greek), 2017-2018.

[23] Dimopoulou, M., Zobolas, T. Babila, E. Skanavi K. and Chatzimichail, M., Study of the Environment, $2^{\text {nd }}$ grade of primary school. Athens, CTI Diophantus (in Greek), 2017-2018.

[24] Kokotas, P. Alexopoulos, D. Malamitsa, K. Mandas, G. Palamara, M. and Panagiotaki, P., Study of the Environment, $3^{\text {rd }}$ grade of primary school. Athens, CTI Diophantus (in Greek), 2017-2018.

[25] Kokotas, P. Alexopoulos, D. Malamitsa, K. Mandas, G. Palamara, M. Panagiotaki, P. and Piliouras, P., Study of the Environment, $4^{\text {th }}$ grade of primary school. Athens, CTI Diophantus (in Greek), 2017-2018.

[26] Koutsopoulos, K. Sotirakou, M. and Tastsoglou, M., Geography, Learn about Greece, $5^{\text {th }}$ grade of primary school. Athens, CTI Diophantus (in Greek), 2017-2018.

[27] Koutsopoulos, K. Sotirakou, M. and Tastsoglou, M., Geography, Learn about the Earth, $6^{\text {th }}$ grade of primary school. Athens, CTI Diophantus (in Greek), 2017-2018.

[28] Pavlopoulos, K. and Galani, A., Geology - Geography, $1^{\text {st }}$ grade of secondary school. Athens, CTI Diophantus (in Greek).

[29] Aslanidis, A., Zafirakidis, G. and Kalaitzidis D., Geology Geography, $2^{\text {nd }}$ grade of secondary school. Athens, CTI Diophantus (in Greek), 2017-2018.

[30] Jennings, T., Oxford International Primary Geography 1. 2015. Oxford University Press, 2015.

[31] Jennings, T., Oxford International Primary Geography 2. 2015. Oxford University Press, 2015.

[32] Jennings, T., Oxford International Primary Geography 3. 2015. Oxford University Press, 2015.

[33] Jennings, T., Oxford International Primary Geography 4. 2015. Oxford University Press, 2015. 
[34] Jennings, T., Oxford International Primary Geography 5. 2015. Oxford University Press, 2015.

[35] Jennings, T., Oxford International Primary Geography 6. 2015. Oxford University Press, 2015.

[36] Galagther, R. and Parish, R., Geog.1.Geography for key stage 3, Oxford University Press, 4th edition (in Spanish), 2014.

[37] Galagther, R. and Parish, R., Geog.2.Geography for key stage 3, Oxford University Press, 4th edition (in Spanish), 2014.

[38] Galagther, R. and Parish, R., Geog.3.Geography for key stage 3, Oxford University Press, 4th edition (in Spanish), 2015.

[39] Social Sciences: Ciencias Sociales 1, Anaya. Series: Aprender es crecer, (in Spanish), 2017.

[40] Social Sciences: Ciencias Sociales 2, Anaya. Series: Aprender es crecer, (in Spanish), 2017.

[41] Social Sciences: Ciencias Sociales 3, Anaya. Series: Aprender es crecer, (in Spanish), 2017.

[42] Social Sciences: Ciencias Sociales 4, Anaya. Series: Aprender es crecer, (in Spanish), 2017.

[43] Social Sciences: Ciencias Sociales 5, Anaya. Series: Aprender es crecer, (in Spanish), 2016.

[44] Social Sciences: Ciencias Sociales 6, Anaya. Series: Aprender es crecer, (in Spanish), 2017.

[45] Geography and History: Geografía e historia.1 ESO, S.M. Savia, (in Spanish), 2015.

[46] Geography and History: Geografía e historia. 2 ESO, S.M. Savia, (in Spanish), 2016.

[47] Geography and History: Geografía e historia. 3 ESO, S.M. Savia, (in Spanish), 2015.

[48] Geography and History: Geografía e historia. 4 ESO, S.M. Savia, 2(in Spanish), 016.

[49] Karatza, A., Galani L. and Chalkia. K., National and European identities, European cultural heritage and the "European Other" in Greek, British and Spanish curricula: A geographical perspective. In Galani, L., E. Mavrikaki and K. Skordoulis (eds.) e-book Geographical literacy and European Heritage: a challenging convention in the field of Education, Solva Tech LTD, Limassol, ISBN: 987-992597439-2-6, 2018, [E-book] Available: https://itunes.apple.com/us/book/geographical-literacy-andeuropean-heritage/id1444840569?ls=1\&mt=11

[50] Theodoropoulos, D., Kyridis, A. Zagkos G. and Konstantinidou Z., "Brain drain" phenomenon in Greece: Young Greek scientists on their way to immigration in an era of "crisis". Attitudes, opinions and beliefs towards the prospect of migration. Journal of Education and Human Development, 3(4): 229-248, 2014.

[51] Mitsiniotou, V., 9 years since crisis hit, Greek brain drain continues, 2016, Retrieved from the Anadolu Agency (AA). http://aa.com.tr/en/economy/9-years-since-crisis-hit-greek-braindrain-continues/593675 (Assessed 2017-01-25).

[52] Europa, Unemployment Statistics, 2017b, http://ec.europa.eu/eurostat/statisticsexplained/index.php/Unemployment_statistics\#Recent_developme nts_in_unemployment_at_a_European_and_Member_State_level (Accessed 2019-01-06).

[53] Europa, Brexit negotiations, 2017a, https://ec.europa.eu/commission/brexit-negotiations_en (Accessed 2019-01-06).

[54] NatCen, British Social Attitudes reveals Britain wants less nanny state, more attentive parent, 2017, http://www.natcen.ac.uk/newsmedia/press-releases/2017/june/british-social-attitudes-revealsbritain-wants-less-nanny-state,-more-attentive-parent/ (Accessed 2019-08-06).

[55] Krippendorff, K., Content analysis: An introduction to its methodology, SAGE, Thousand Oaks, 2004

[56] https://www.nationalgeographic.org/news/geo-literacypreparation-far-reaching-decisions/ (Accessed 2019-02-07).

[57] Edelson, D. C., Geo-Literacy Preparation for Far-Reaching Decisions, 2014.

[58] Galani, L., Karatza, A. and Siozi, N., Activity Book - Brochures for Educators In Galani, L. (ed.) e-book Communicating Critical Heritage and geography with pupils, Solva Tech LTD, Limassol, ISBN: 978-9925-7439-1-9, 2018, [E-book] Available: http://www.solvatech.com.cy/books/Brochures_COHERE_NKUA _2018.pdf (Accessed 2019-10-17).

[59] CoHERE Critical Archive (CCA), Communicating Critical Heritage and geography with pupils" Activity Book - Brochures for Educator, 2018, http://cohere-ca.ncl.ac.uk/\#/grid/409 (Accessed 2019-11-12).

[60] Galani, L., Reinforcing Heritage dialogue through «Eurocraft» serious game prototype. Istanbul Bilgi University European Institute Newsletter, 11:29, 2018, https://eu.bilgi.edu.tr/media/files/NEWSLETTER_2018_A4_2.pdf. (Accessed 2019-10-21).

[61] CoHERE Critical Archive (CCA), Technological Tools: Eurocraft: Explore Critical Heritages through Vid-maps (Beta Version.), 2018, http://cohere-ca.ncl.ac.uk/\#/grid/446 (Accessed 2019-07-12).

(C) The Author(s) 2019. This article is an open access article distributed under the terms and conditions of the Creative Commons Attribution (CC BY) license (http://creativecommons.org/licenses/by/4.0/). 